\title{
Arsenic contamination of groundwater in the Kathmandu Valley, Nepal, as a consequence of rapid erosion
}

\author{
*Steven H. Emerman ${ }^{1}$, Tista Prasai ${ }^{2}$, Ryan B. Anderson ${ }^{1}$, and Mallory A. Palmer ${ }^{1}$ \\ ${ }^{1}$ Department of Earth Science, Utah Valley University, Orem, Utah 84058, USA \\ ${ }^{2}$ Nepal Academy of Science and Technology, Lalitpur, Nepal \\ (*Email: stevene@uvu.edu)
}

\begin{abstract}
Elevated levels of arsenic (As) in groundwater in the flood plain of the Ganges River have been well-documented over the past decades. The objective of this study was to measure As and the transition elements normally associated with As in the Kathmandu Valley in Nepal, a heavily populated tectonic valley in the upper reaches of the Ganges River system. Water samples were collected from six shallow tubewells (depth $<50 \mathrm{~m}$ ), eight deep tubewells and 13 dug wells and stone spouts. Electrical conductivity, temperature and $\mathrm{pH}$ were measured on-site and concentrations of $\mathrm{As}, \mathrm{Fe}, \mathrm{Cu}, \mathrm{Ni}, \mathrm{Co}, \mathrm{Mn}, \mathrm{Zn}$ and $\mathrm{Cr}$ were measured with a spectrophotometer. Five tubewells and four dug wells had As levels exceeding the Nepal Interim Standard (As $=0.05 \mathrm{mg} / \mathrm{L})$. There was no statistically significant clustering of As levels either with depth or horizontal location. Arsenic was uncorrelated with either Fe $\left(R^{2}=0.096\right), \mathrm{Mn}\left(\mathrm{R}^{2}=0.0004\right)$ or any combination of transition elements $\left(\mathrm{R}^{2}<0.083\right)$, which is inconsistent with both the reduction-dissolution and the sulfide oxidation models for As release. The geometric mean As level of groundwater $(\mathrm{As}=0.015 \mathrm{mg} / \mathrm{L})$ was indistinguishable from the geometric mean As level of surface water (As $=0.013 \mathrm{mg} / \mathrm{L}$ ) obtained from 48 river samples from the Kathmandu Valley in a previous study. We are suggesting that elevated groundwater As results not from subsurface redox conditions, but from losing streams with elevated As, which is a consequence of rapid erosion caused by a combination of monsoon climate, tectonic uplift and deforestation.
\end{abstract}

Keywords: Arsenic, erosion, fluvial, groundwater, runoff, Kathmandu, Nepal

Received: December 2, 2009

Revision accepted: April 10, 2010

\section{INTRODUCTION}

The widespread contamination of groundwater with As in the flood plain of the Ganges River in Bangladesh and West Bengal (India) has been well-documented over the past 15 years (Bhattacharaya et al. 1997; Dhar et al. 1997; Nickson et al. 1998). Studies over the past eight years have documented that the region of As contamination extends even into the Terai region, the Indo-Gangetic Plain of southern Nepal (Neku and Tandukar 2002; Bhattacharya et al. 2003; Shrestha et al. 2003; ENPHO and USGS 2004; Kanel et al. 2005; Tandukar et al. 2005; Brikowski et al. 2006; Neku et al. 2006; Panthi et al. 2006; Neku and Brikowski 2009; Pokhrel et al. 2009) (Fig. 1). According to the most recent count, 25,058 tubewells in the Terai region have been tested for As, of which 5,686 tubewells (22.7\%) exceed the WHO (World Health Organization) As Standard (As $=0.01 \mathrm{mg} / \mathrm{L}$ ) and 1,916 tubewells (7.6\%) exceed the Nepal Interim As Standard (As $=0.05 \mathrm{mg} / \mathrm{L})$ (Panthi et al. 2006). It is estimated that there are perhaps 200,000 tubewells in the Terai region and that 3.5 million Nepalese have no access to drinking water that does not exceed the WHO As Standard (Pokhrel et al. 2009). Other studies in the Terai have addressed the geological setting of As contamination (Shrestha et al. 2004; Williams et al. 2004, 2005; Brikowski et al. 2005; Gurung et al. 2005; Van Geen et al. 2008), the impact of As-contaminated groundwater upon the local population (Ahmad et al. 2004; Maharjan et al. 2005, 2006, 2007) and the As contamination of soils and crops (Dahal et al. 2008).

Possible responses to As contamination of groundwater could be placed into the following five categories:

1) Treatment could be provided to those members of the local population who show symptoms of arsenicosis,

2) The health of the local population could be improved, especially with regard to nutrition, so that people who drink As-contaminated water do not develop symptoms of arsenicosis,

3) The water from tubewells that are contaminated with As could be treated so as to remove the As,

4) Tubewells could be drilled into aquifers that are not contaminated with As (or in other ways the local population could be provided with water that is not contaminated with As), and

5) Steps could be taken to prevent further contamination of groundwater with As.

Most current work is in categories \#3 and \#4, either developing more effective and less costly means of removing As from groundwater (Neku and Tandukar 2003) or searching 


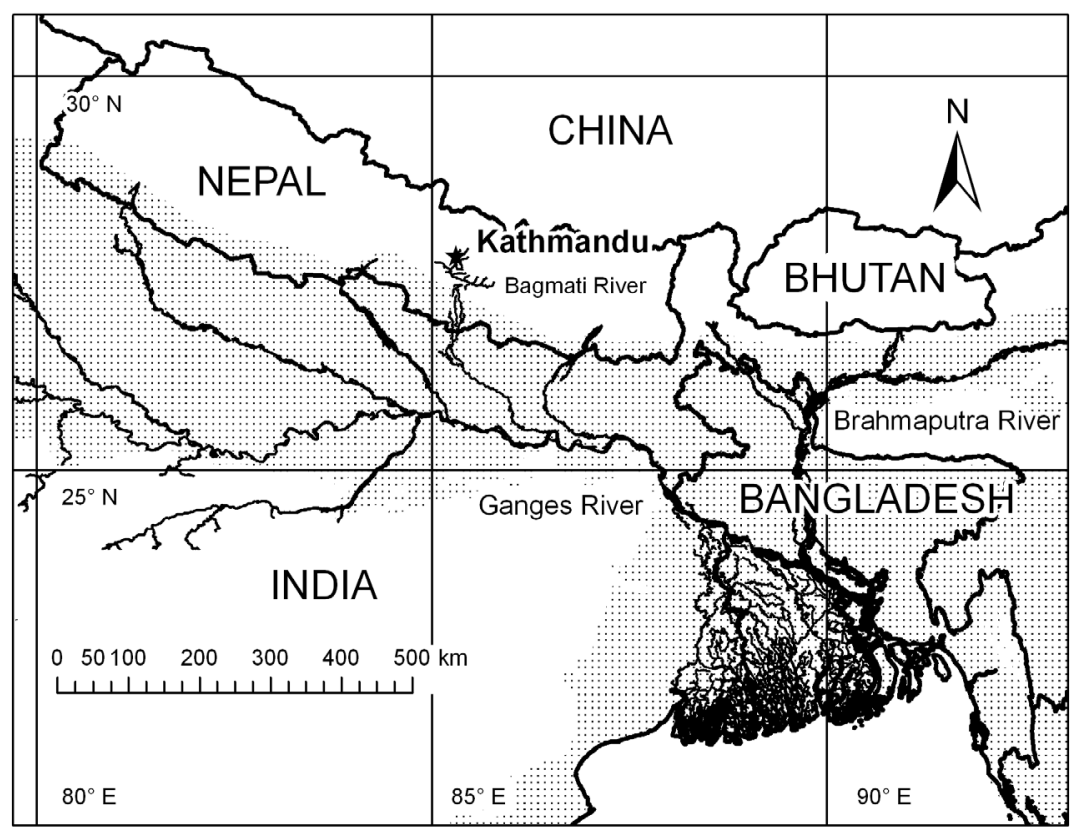

Fig. 1: The Kathmandu Valley is a heavily populated tectonic valley in the upper reaches of the Ganges River system (Hearn et al. 2001). Most of the tributaries of the Ganges River in Nepal are not shown in order to emphasize the Bagmati River

for the aquifers that are not contaminated with As (Brikowski et al. 2004, 2005; Winkel et al. 2008). Category \#5 cannot be addressed without knowledge of the cause of As contamination.

It has been generally agreed for a long time that the As contamination of groundwater is too widespread to be due to direct human activities such as mining, smelting or the use of As-based pesticides (Aswathanarayana 1997). The following six models have been proposed for the release of As into groundwater in the Indo-Gangetic Plain, some of which involve indirect human activity:

1) Overpumping of aquifers has caused oxidation of sulfide minerals and release of co-precipitated As into groundwater (Badal et al. 1996; Mallick and Rajgopal 1996).

2) Excessive use of phosphate fertilizers has resulted in displacement of As from sediment adsorption sites by phosphate (Acharyya et al. 1999, 2000).

3 ) Arsenic that is co-precipitated with diagenetic carbonate concretions is released into groundwater upon dissolution of the carbonate concretions under acidic conditions (Shanker et al. 2001).

4) Arsenic is displaced from adsorption sites by carbonate after sediments deposited in surface waters with low carbonate concentration are later exposed to groundwater with high carbonate concentration (Appelo et al. 2002).

5) The loss of healthy forests and grasslands causes the loss of the microbial population that sequesters As in soil so that As is leached into groundwater (Emerman 2004; Emerman et al. unpub.).

6) In the strongly reducing conditions of the thick sedimentary cover of the Indo-Gangetic Plain, As is released from adsorption sites on Fe oxyhydroxides after dissolution of the Fe oxyhydroxides by microorganisms (Nickson et al. 2000; McArthur et al. 2001; Bose and Sharma 2002; Harvey et al. 2002) or after reduction of adsorbed As from $\mathrm{As}^{+5}$ (arsenate) to $\mathrm{As}^{+3}$ (arsenite) (Bose and Sharma 2002).

The reductive-dissolution model (Model \#6) has gradually become the dominant paradigm in As studies in South Asia. The important implication of the reductivedissolution model is that As contamination does not result from even indirect human activity and that nothing can be done to reduce the input of As. It is, of course, necessary to continually re-evaluate all of the above models in light of every new set of data that is collected. For example, Williams et al. $(2004,2005)$ have argued that As contamination in the Terai region could result from sulfide oxidation (Model \#1) rather than reductive-dissolution. Polizzotto et al. (2006) have produced a cogent criticism of the reductive-dissolution model based upon observations and experiments on sediments from Bangladesh.

What all of the above models have in common is that they draw attention to the environmental conditions existing in the soil or sedimentary package and have no role for fluvial As. However, Emerman (2005) and Emerman et al. (2007) found elevated As in rivers in the Kathmandu Valley and 
throughout central and eastern Nepal outside of the Higher Himalayan Zone. Emerman (2005) measured fluvial As six times monthly in eight rivers in the Kathmandu Valley and found mean fluvial As exceeding the WHO As Standard (As $=0.01 \mathrm{mg} / \mathrm{L})$ in all but one river. Emerman (2005) and Emerman et al. (2007) also collected 115 fluvial samples from 30 locations outside of the Kathmandu Valley and the Higher Himalayan Zone and found that $53 \%$ of samples met or exceeded the WHO As Standard. By contrast, the global background fluvial As is in the range $0.00013-0.0021 \mathrm{mg} / \mathrm{L}$ (Smedley and Kinniburgh 2002). Emerman et al. (2007) questioned whether it could be a coincidence that rivers with elevated As are draining into sedimentary basins in which the groundwater has elevated As. They suggested that while all of the above models could be thermodynamically plausible, the kinetics could be sufficiently slow that the groundwater chemistry simply reflects the surface water chemistry. This leads to the last model for As contamination in South Asia.

7) Groundwater is recharged by losing streams with elevated As due to rapid erosion caused by monsoon climate, tectonic uplift and deforestation (fluvial recharge model).

Rapid erosion should lead to increased concentrations of all elements in rivers because, as the rate of erosion increases, a given volume of rainfall will result in the release of a larger mass of each element from rock, sediment or soil into overland flow, whether the rapid erosion is due to the high-intensity rainfall events of monsoon climate, the steep slopes resulting from tectonic uplift or the lack of surface cover resulting from deforestation or excessive grazing. A similar argument explains why rivers become more turbid as the river stage rises (Bloom 1998). The above argument should apply especially to As, which occurs in aqueous form predominantly as the oxyanion $\mathrm{AsO}_{4}^{-3}$. Most ions will tend to adsorb onto sediment during the course of overland flow. Much of the sediment that is eroded from a watershed will not exit the mouth of the watershed, but will be redistributed throughout the watershed, in accordance with the geomorphic principle that smaller landforms erode faster than larger landforms (Bloom 1998). On that basis, much of the mass of elements that are released into overland flow during rapid erosion will not appear in rivers, although most of the water involved in overland flow will appear in rivers. However, the As oxyanion will not tend to adsorb onto sediment during rapid overland flow. First, sediment tends to have many fewer positively charged sorption sites than negatively charged sorption sites. Second, the As oxyanion has both much greater mass and volume than the elements that occur in aqueous form as cations or monatomic anions, and greater mass than the other common oxyanions $\mathrm{NO}_{3}^{-3}$ and $\mathrm{PO}_{4}^{-3}$. Since all ions in overland flow are travelling with the same velocity, the As oxyanion will have much greater kinetic energy than the other ions and will tend to "bounce" off of sorption sites. To put it in another way, a trivalent As oxyanion cannot attach to three positively-charged sorption sites unless it has sufficient residence time in the vicinity of the sorption sites for all three sites to become simultaneously vacant, for example, by diffusion of three monovalent chloride ions from sorption sites into water. Moreover, the large volume of the As oxyanion implies that the region of the three sorption sites must be sufficiently large for the As oxyanion to attach. The result is that the As oxyanion cannot attach to sorption sites when the overland flow is rapid so that most of the As that is released into overland flow by rainfall will appear in rivers rather than be adsorbed onto sediment that is deposited within the watershed.

We are not aware of any previous discussion of the above hypotheses concerning the effect of rapid erosion on fluvial As or the behavior of As in overland flow despite the importance of the behavior of As to public health. The above ideas could be tested by showing that a mixture of sediment and water could be stirred sufficiently fast in the laboratory that As cannot adsorb onto sediment, in contrast to other elements, especially the smaller cations, which will adsorb onto sediment. Another test could be showing that, as the erosion rate increases, the concentration of fluvial As will increase faster than the concentrations of the other elements. It is well-known in the agricultural literature that fluvial concentrations of nitrate and phosphate increase rapidly as erosion rate increases, but this is normally attributed solely to the lack of positively charged sites on sediment, rather than to the mass and volume of the oxyanions. Naturally occurring elevated levels of fluvial As have been reported elsewhere in the world, although they have been attributed to input of geothermal waters (McLaren and Kim 1995; Robinson et al. 1995; Nimick et al. 1998; Wilkie and Hering 1998) or evaporative concentration of baseflow-dominated rivers in arid areas (Cáceres et al. 1992; Lerda and Prosperi 1996; Smedley and Kinniburgh 2002). It is possible that elevated fluvial As in Nepal results from a "perfect storm" of monsoon climate, tectonic uplift and deforestation.

The objective of this study was to examine the occurrence of elevated As in groundwater in the Kathmandu Valley, a heavily populated tectonic valley in the upper reaches of the Ganges River system, well outside of the Indo-Gangetic flood plain (Fig. 1). The specific goals were:

- to test the fluvial recharge model by comparing concentrations of As in groundwater and surface water,

- to test the reductive-dissolution model by comparing As concentrations with $\mathrm{Fe}$ and $\mathrm{Mn}$ concentrations in groundwater,

- to test the sulfide oxidation model by comparing As concentrations with concentrations of the transition elements that are normally associated with As, and

- to determine whether there is clustering of As concentrations by depth or horizontal location.

This study has built upon the substantial number of studies of water quality dealing with parameters other than As in the Kathmandu Valley (Cresswell et al. 2001; Karn and Harada 2001; Singh 2004; Bhatt and McDowell 2007; 


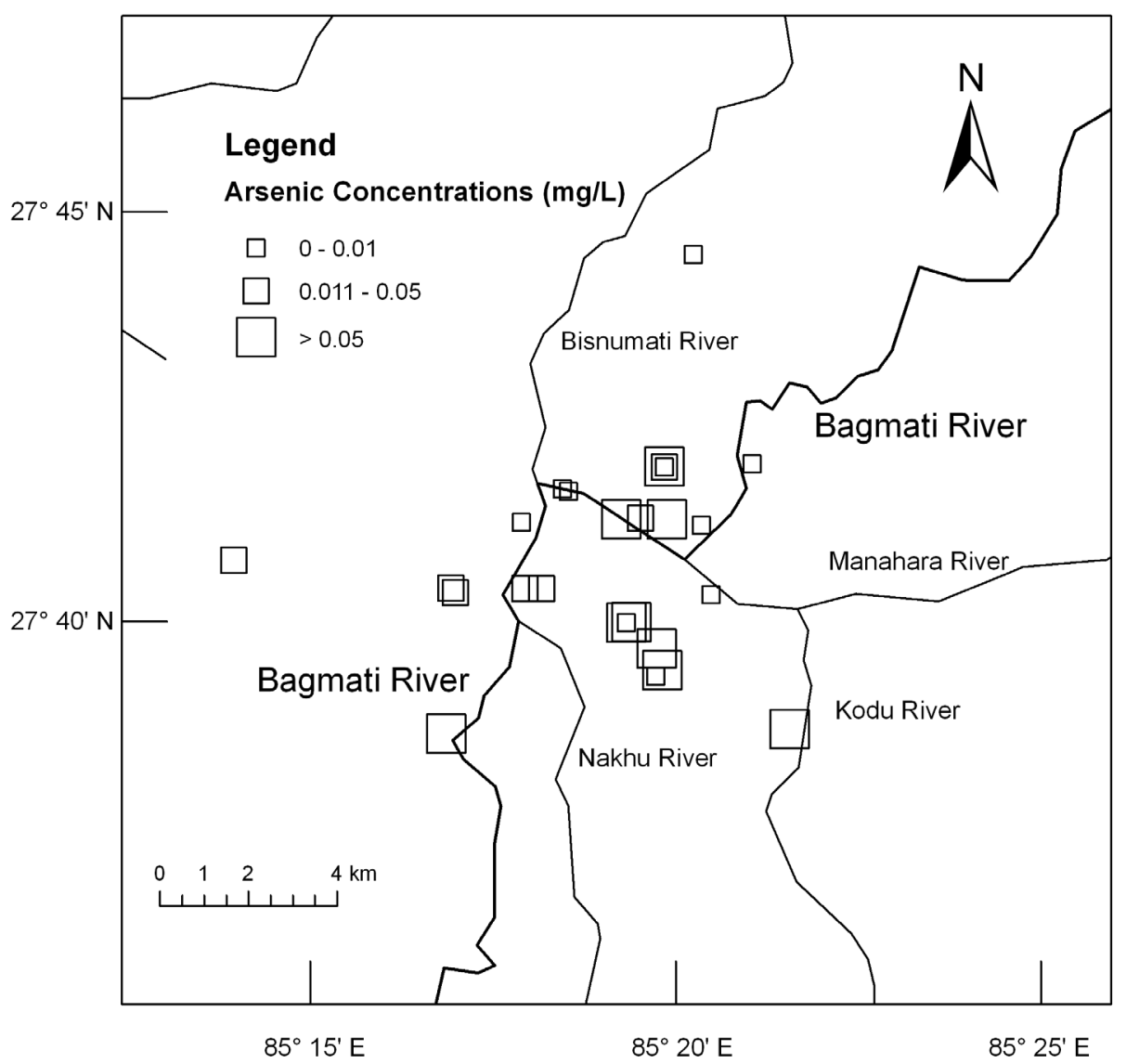

Fig. 2: Groundwater samples collected from 14 tubewells, 13 dug wells and stone spouts throughout the Kathmandu Valley (Hearn et al. 2001). Arsenic concentrations were classified as meeting the WHO As Standard $(\leq 0.01 \mathrm{mg} / \mathrm{L})$, exceeding the WHO As Standard but meeting the Nepal Interim As Standard (0.011 - 0.05 mg/L), or exceeding the Nepal Interim As Standard $(>0.05 \mathrm{mg} / \mathrm{L}$.

Chapagain et al. in press), Nepal (Chettri and Smith 1995; Collins and Jenkins 1996; Dongol et al. 2005) and the Central Himalaya (Sharma et al. 2005).

\section{MATERIALS AND METHODS}

Water samples were collected from six shallow tubewells (depth $<50 \mathrm{~m}$ ), eight deep tubewells, 12 dug wells and one stone spout over about a $120 \mathrm{~km}^{2}$ area of the Kathmandu Valley during May and June 2009 (pre-monsoon) (Fig. 2). All wells were pumped for several minutes to purge the well of any water in contact with the atmosphere or the well screen or casing. Electrical conductivity, $\mathrm{pH}$ and temperature were measured on site with the Oakton PCSTester 35. Water was forced through a $0.45-\mu \mathrm{m}$ syringe filter into two $250-\mathrm{mL}$ polyethylene containers with the contents of one container used for measurement of As and the other used for all other heavy metals. Trace metal grade concentrated nitric acid was added to reduce $\mathrm{pH}<2$ (Saunders 1998). Prior to analysis for all metals beside As, concentrated $\mathrm{NaOH}$ was added to raise $\mathrm{pH}$ to the range 4-5. Concentrations of Fe, $\mathrm{Cu}, \mathrm{Ni}, \mathrm{Co}, \mathrm{Mn}, \mathrm{Zn}$ and $\mathrm{Cr}$ were measured in Nepal within one week using the Hach DR-2700 Spectrophotometer. Water samples were returned to Utah Valley University for measurement of As using the silver diethyldithiocarbamate method (U.S. Environmental Protection Agency Standard Method 3500-As) with the Hach DR-2700 Spectrophotometer. The spectrophotometer was re-calibrated after every 15 samples using three standard solutions with As concentrations of $0.02 \mathrm{mg} / \mathrm{L}, 0.04 \mathrm{mg} / \mathrm{L}$ and $0.2 \mathrm{mg} / \mathrm{L}$. All analyses were completed within six months of sampling. The detection limits were $0.001 \mathrm{mg} / \mathrm{L}$ for $\mathrm{As}, \mathrm{Ni}$ and $\mathrm{Co}, 0.01 \mathrm{mg} /$ $\mathrm{L}$ for $\mathrm{Fe}, \mathrm{Cu}, \mathrm{Zn}$ and $\mathrm{Cr}$, and $0.1 \mathrm{mg} / \mathrm{L}$ for $\mathrm{Mn}$.

\section{RESULTS}

Three shallow tubewells (50\% of samples) and two deep tubewells (25\% of samples) exceeded both the WHO and Nepal Interim As Standards. The WHO As Standard was exceeded by 11 dug wells and stone spouts ( $85 \%$ of samples), while four dug wells and stone spouts (31\% of samples) also exceeded the Nepal Interim As Standard (Table 1). Health facilities with As values exceeding the Nepal Interim As Standard included Paropkhar Maternity and Women's 
Table 1: Description of sampling sites and arsenic concentrations

\begin{tabular}{|c|c|c|c|c|c|c|}
\hline As Rank & As (mg/L) & Description & Type* & Depth (m) & Latitude & Longitude \\
\hline 1 & 2.07 & Paropakar Maternity Hospital & TW & 100 & 27.6888475 & 85.3194883 \\
\hline 2 & 0.83 & Private Home & DW & 14 & 27.6996878 & 85.3292728 \\
\hline 3 & 0.5 & Private Home & TW & 8 & 27.6889353 & 85.3300369 \\
\hline 4 & 0.438 & Satdobato Well & DW & 9 & 27.6625636 & 85.3280883 \\
\hline 5 & 0.32 & Lagankhel Mental Hospital & TW & 14 & 27.6678953 & 85.3221606 \\
\hline 6 & 0.199 & Patan Mental Hospital & TW & 244 & 27.667731 & 85.3210724 \\
\hline 7 & 0.186 & Chalnakhel Artesian Well & TW & 15 & 27.6445742 & 85.2801928 \\
\hline 8 & 0.074 & Private Home & DW & 7 & 27.6465122 & 85.3587192 \\
\hline 9 & 0.067 & Private Home & DW & 15 & 27.6581161 & 85.3293703 \\
\hline 10 & 0.034 & Private Home & DW & 10 & 27.6733847 & 85.2818092 \\
\hline 11 & 0.026 & Private Home & DW & 12 & 27.6744075 & 85.3015492 \\
\hline 12 & 0.023 & Private Home & DW & 2 & 27.6995983 & 85.3292531 \\
\hline 13 & 0.02 & Private Home & DW & 4 & 27.689125 & 85.3239244 \\
\hline 14 & 0.014 & Private Home & DW & 9 & 27.6742258 & 85.2807675 \\
\hline 15 & 0.012 & Private Home & DW & $<50$ & 27.6744283 & 85.2976922 \\
\hline 16 & 0.011 & Matatirtha & SS & 3 & 27.67932 & 85.2309344 \\
\hline 17 & 0.002 & Private Home & TW & 8 & 27.7430111 & 85.3352531 \\
\hline 18 & 0.001 & Metro Apartment & TW & 46 & 27.6879325 & 85.2966578 \\
\hline 19 & 0.001 & Sunrise Home & TW & 244 & 27.6736519 & 85.3402775 \\
\hline 20 & 0 & Private Home & DW & 6 & 27.6995983 & 85.3292531 \\
\hline 21 & 0 & Patan Mental Hospital & TW & $>50$ & 27.667731 & 85.3210724 \\
\hline 22 & 0 & Teku Tropical Hospital & TW & 91 & 27.6948867 & 85.3059675 \\
\hline 23 & 0 & Lifestyle Housing & TW & 260 & 27.6943892 & 85.3073464 \\
\hline 24 & 0 & Oriental Colony & TW & 200 & 27.6879325 & 85.2966578 \\
\hline 25 & 0 & Kathmandu Upatyaka Khanepani & TW & 145 & 27.6877703 & 85.3379456 \\
\hline 26 & 0 & Private Home & TW & 23 & 27.7004631 & 85.3493122 \\
\hline 27 & 0 & NAST (Nepal Acad. Sci. Tech.) & DW & 12 & 27.6568378 & 85.3279103 \\
\hline
\end{tabular}

$* T W=$ tubewell $($ drilled well), DW $=$ dug well, $S S=$ stone spout

Hospital (As $=2.07 \mathrm{mg} / \mathrm{L})$, Lagankhel Mental Hospital (As $=0.320 \mathrm{mg} / \mathrm{L})$, and Patan Mental Hospital $(\mathrm{As}=0.199 \mathrm{mg} / \mathrm{L})$. Patan Mental Hospital has an additional deep tubewell with no detectable As. None of the above health facilities uses water from the tubewells for drinking or cooking. The WHO drinking water standards were exceeded by 18 samples $(67 \%)$ for $\mathrm{Mn}(\mathrm{Mn}>0.2 \mathrm{mg} / \mathrm{L}), 13$ samples $(48 \%)$ for $\mathrm{Fe}(\mathrm{Fe}>0.3$ $\mathrm{mg} / \mathrm{L})$ and one sample $(4 \%)$ for $\mathrm{Cu}(\mathrm{Cu}>1 \mathrm{mg} / \mathrm{L})$ (Table 2). For $\mathrm{Mn}, \mathrm{Fe}$ and $\mathrm{Cu}, \mathrm{WHO}$ standards do not differ from the Nepal National Drinking Water Quality Standards (Warner et al. 2008).

It is crucial to test for the existence of normal distributions prior to using any statistical tests that assume normal distributions. For each element, the mean and standard deviation were calculated and the cumulative percentage for each concentration (percentage of concentrations equal to or less than that concentration) were compared with the cumulative percentage for a normal distribution with the same mean and standard deviation. None of the elements measured in groundwater followed a normal distribution (Fig. 3a). The concentrations tended to be very positively skewed so that most of the concentrations were low, but with a long tail of higher concentrations. On the other hand, comparing the cumulative percentage of each concentration of each element with the cumulative percentage of the equivalent lognormal distribution (same mean and standard deviation as the set of logarithms of concentrations) shows that all elements except $\mathrm{Cr}$ follow a lognormal distribution (Fig. 3b). The use of a lognormal distribution requires an assumption about the zero concentrations (concentrations below the detection limit). We set all zero concentrations equal to the detection limit. In the case of $\mathrm{Cr}, 14$ samples $(52 \%)$ were below the detection limit, while another six samples $(22 \%)$ were measured at the detection limit (Table 2), which would make it impossible to fit a lognormal distribution. The same statistical tests were carried out to determine whether the 48 samples of surface water for which concentrations of As, $\mathrm{Fe}, \mathrm{Cu}, \mathrm{Ni}, \mathrm{Co}$ and $\mathrm{Zn}$ measured in the Kathmandu Valley by Emerman (2005) followed a normal or lognormal distribution. Emerman (2005) did not measure Mn or Cr in surface water. The distributions of surface water $\mathrm{As}, \mathrm{Fe}$ and $\mathrm{Cu}$ follow a normal distribution, while the other elemental concentrations are positively skewed, although not as positively skewed as the concentrations in groundwater (Fig. 3c). All surface water concentrations were a reasonable fit to a lognormal distribution with the possible exception of $\mathrm{Zn}$ (Fig. 3d). In the case of $\mathrm{Zn}$ in surface water, 19 samples (40\%) were below the detection limit, while another six samples $(12.5 \%)$ were measured at the detection limit. On the above basis, we 


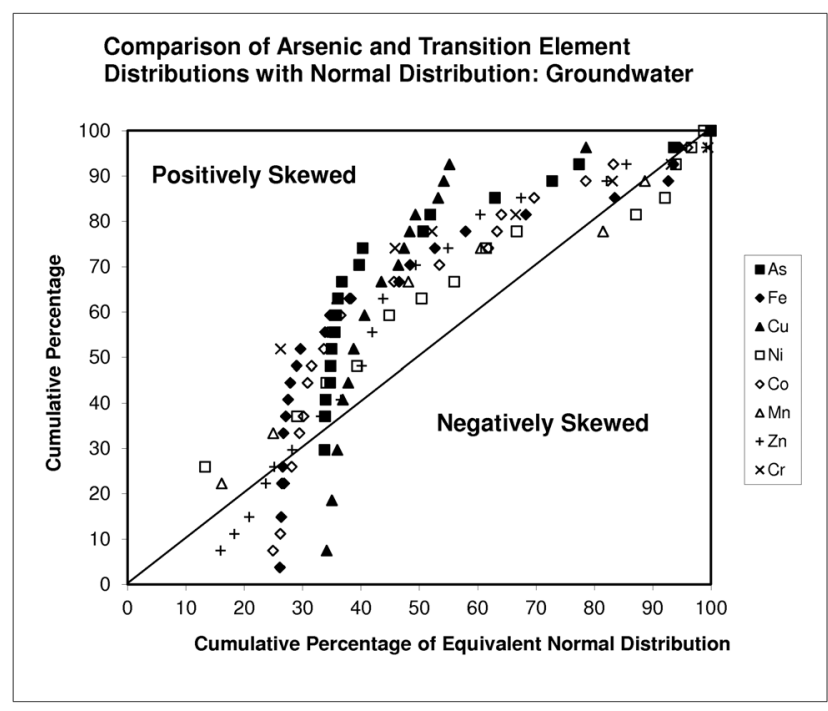

Fig. 3a: For each measured concentration of $\mathrm{As}, \mathrm{Fe}, \mathrm{Cu}, \mathrm{Ni}$, $\mathrm{Co}, \mathrm{Mn}, \mathrm{Zn}$ and $\mathrm{Cr}$ in groundwater, the percentage of measured concentrations less than or equal to that value is plotted against the percentage that would result from a normal distribution with the same mean and standard deviation as the set of measured concentrations. None of the parameters follow a normal distribution

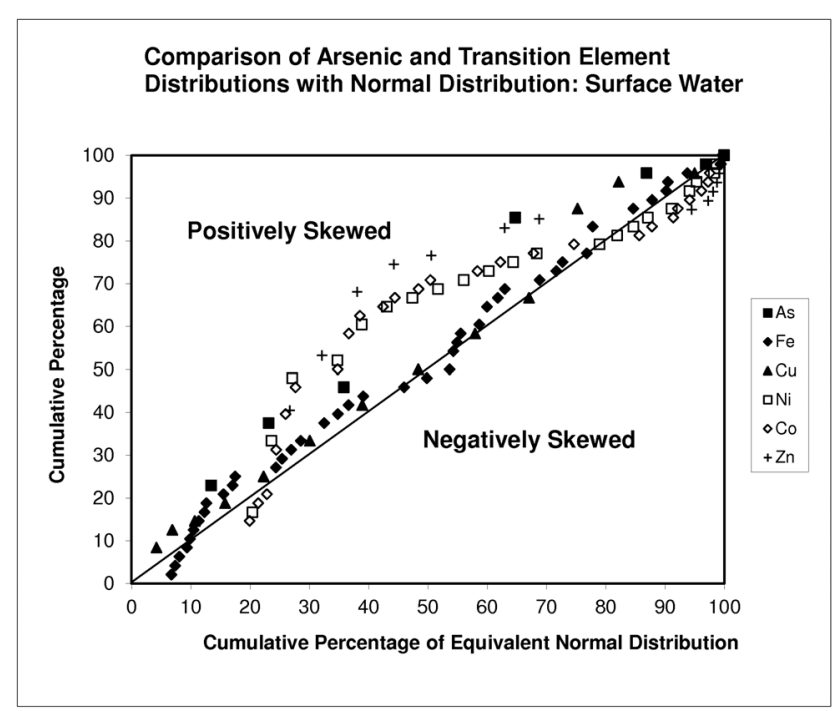

Fig. 3c: For each measured concentration of $\mathrm{As}, \mathrm{Fe}, \mathrm{Cu}, \mathrm{Ni}$, $\mathrm{Co}$, and $\mathrm{Zn}$ in surface water, the percentage of measured concentrations less than or equal to that value is plotted against the percentage that would result from a normal distribution with the same mean and standard deviation as the set of measured concentrations. The parameters As, Fe, and $\mathrm{Cu}$ follow a normal distribution, but $\mathrm{Ni}, \mathrm{Co}$ and $\mathrm{Zn}$ do not.

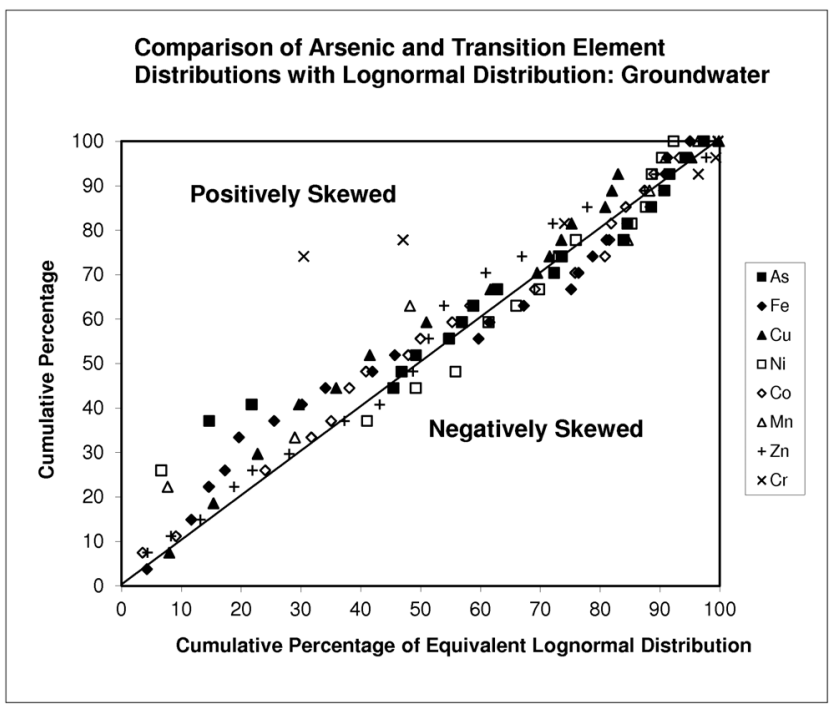

Fig. 3b: For each measured concentration of $\mathrm{As}, \mathrm{Fe}, \mathrm{Cu}, \mathrm{Ni}$, $\mathrm{Co}, \mathrm{Mn}, \mathrm{Zn}$ and $\mathrm{Cr}$ in groundwater, the percentage of measured concentrations less than or equal to that value is plotted against the percentage that would result from a lognormal distribution with the same mean and standard deviation as the set of logarithms of measured concentrations. Values below the detection limit are set equal to the detection threshold. All of the parameters follow a lognormal distribution with the exception of $\mathrm{Cr}$, for which $52 \%$ of the measurements are below the detection limit.

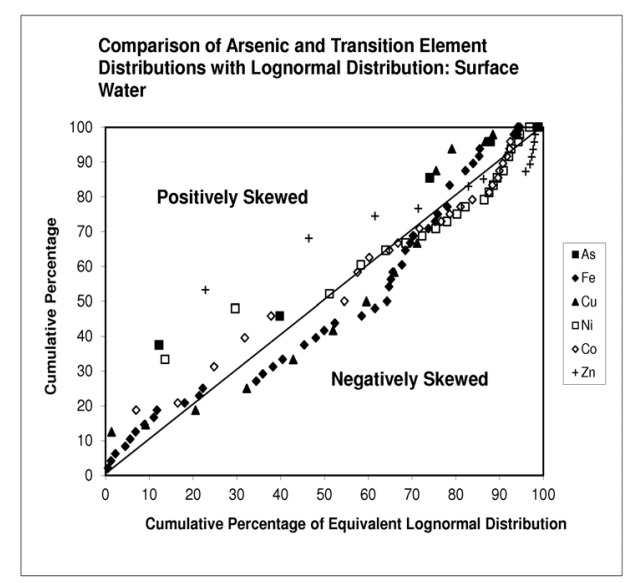

Fig. 3d: For each measured concentration of $\mathrm{As}, \mathrm{Fe}, \mathrm{Cu}, \mathrm{Ni}$, $\mathrm{Co}$, and $\mathrm{Zn}$ in surface water, the percentage of measured concentrations less than or equal to that value is plotted against the percentage that would result from a lognormal distribution with the same mean and standard deviation as the set of logarithms of measured concentrations. Values below the detection limit are set equal to the detection threshold. All of the parameters follow a lognormal distribution with the exception of $\mathrm{Zn}$, for which $40 \%$ of the measurements are below the detection limit. 


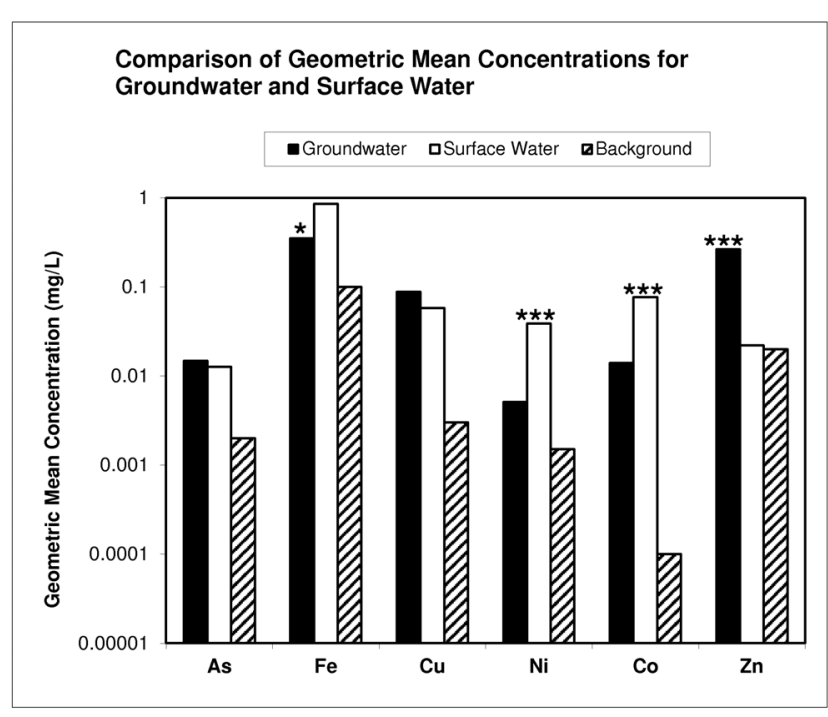

Fig. 4: The symbols $*, *$, *** indicate differences between geometric means of concentrations in groundwater and surface water for a given parameter are statistically significant at the $95 \%, 99 \%$ and $99.9 \%$ confidence levels according to the Student's t-test. Differences between concentrations of $\mathrm{As}$ and $\mathrm{Cu}$ in groundwater and surface water are not statistically significant. Concentrations of all elements are elevated in comparison with global background concentrations (Langmuir 1997) with the exception of $\mathrm{Zn}$ in surface water.

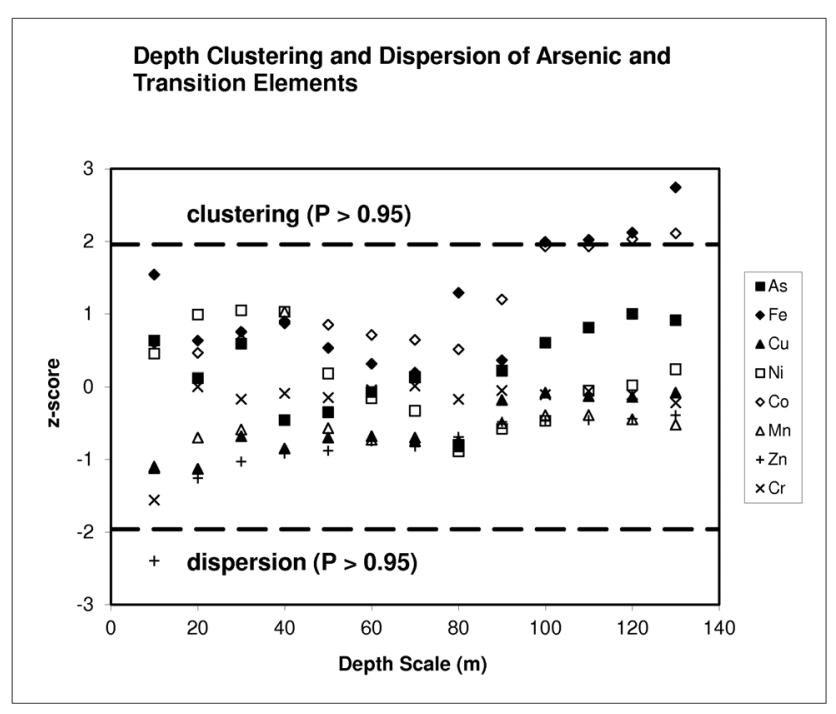

Fig. 5: Similar concentrations of both $\mathrm{Fe}$ and $\mathrm{Co}$ are clustered at depth scales $\geq 100 \mathrm{~m}$. No other elements, including As, show clustering at any depth scale. The $\mathrm{z}$-score is calculated using the Global Moran's I-Test and the logarithms of concentrations $(\mathrm{mg} / \mathrm{L})$ in which values below the detection limit are set equal to the detection threshold (Mitchell 2005). decided to carry out all statistical tests on the logarithms of concentrations with concentrations below the detection limit set equal to the detection limit.

The fluvial recharge model was tested by using the Student's t-test to compare the geometric mean concentrations for groundwater and surface water. Groundwater and surface water concentrations were indistinguishable for both $\mathrm{As}$ and $\mathrm{Cu}$, indicating that no sedimentary geochemical processes are required to explain the levels of groundwater As and $\mathrm{Cu}$ (Fig. 4). On the other hand, Ni, Co and $\mathrm{Fe}$ were much higher in surface water than groundwater, while Zn was much higher in groundwater (Fig. 4), so that asking what sedimentary geochemical processes are causing adsorption of $\mathrm{Ni}$, Co or Fe onto sediment or release of $\mathrm{Zn}$ from sediment into groundwater are reasonable questions. Emerman (2005) found that the elevated levels of $\mathrm{As}, \mathrm{Cu}, \mathrm{Ni}$ and $\mathrm{Co}$ were no higher in the polluted rivers of Kathmandu Valley than in the rest of central Nepal. Further evidence for the natural origin of fluvial As throughout Nepal is the good relation between fluvial As and the typical As concentrations of the watershed bedrock. For example, rivers in the Higher Himalayan Zone do not have elevated As, which is consistent with the typical low As concentrations of high-grade metamorphic rocks (Emerman et al. 2007). On the other hand, Emerman (2005) found significantly higher Fe in the rivers of the Kathmandu Valley than in the rest of central Nepal and suggested that fluvial Fe contamination was due to the many rusted pipes that discharge directly into rivers in the Kathmandu Valley.

The reductive-dissolution model was tested by comparing the concentration of As in groundwater with concentrations of $\mathrm{Fe}$ and $\mathrm{Mn}$. Arsenic was uncorrelated with both Fe $\left(\mathrm{R}^{2}=0.096\right)$ and $\mathrm{Mn}\left(\mathrm{R}^{2}=0.0004\right)$. Even the very poor correlations showed a negative relation, while the reductive-dissolution model predicts positive relations between As and both Fe and Mn, due to the breakdown of Fe oxyhydroxides and release of As under reducing conditions, and the lack of dissolved $\mathrm{Mn}(\mathrm{Mn} \leq 0.2 \mathrm{mg} / \mathrm{L})$ that should occur under oxidizing conditions (Van Geen et al. 2008). The sulfide-oxidation model was tested by comparing the concentration of As in groundwater with concentrations of the transition elements. There were no correlations between As and any combinations of transition elements. The lack of correlation between $\mathrm{As}$ and $\mathrm{Fe}$ is inconsistent with both the reductive-dissolution and the sulfide-oxidation models. The relation between As and the molar sum of the five transition elements most commonly associated with $\mathrm{As}$ ( $\mathrm{Fe}, \mathrm{Cu}, \mathrm{Ni}, \mathrm{Co}, \mathrm{Zn}$ ) (Boyle and Jonasson $1973)$ was negative and very poorly correlated $\left(R^{2}=0.083\right)$. The sulfide-oxidation model could have been further tested by comparing As concentrations with sulfate concentrations, which were not measured.

Moran's Global I-test (Mitchell 2005) performed on the logarithms of concentrations did not show either clustering or dispersion of As concentrations with depth over any depth scale, meaning that this data set did not identify particular depths where elevated As is more or less likely (Fig. 5). The 
Table 2: Groundwater geochemistry in the Kathmandu Valley

\begin{tabular}{|c|c|c|c|c|c|c|c|c|c|c|c|}
\hline As Rank & $\mathbf{p H}$ & $\mathbf{E C}(\boldsymbol{\mu S} / \mathbf{c m})$ & $\mathbf{T e m p} .\left({ }^{\circ} \mathbf{C}\right)$ & $\mathbf{F e}(\mathbf{m g} / \mathbf{L})$ & $\mathbf{C u}(\mathbf{m g} / \mathbf{L})$ & $\mathbf{N i}(\mathbf{m g} / \mathbf{L})$ & $\mathbf{C o}(\mathbf{m g} / \mathbf{L})$ & $\mathbf{M n}(\mathbf{m g} / \mathbf{L})$ & $\mathbf{Z n}(\mathbf{m g} / \mathbf{L})$ & $\mathbf{C r}(\mathbf{m g} / \mathbf{L})$ \\
\hline 1 & 6.8 & 573 & 28.2 & 0.03 & 0.06 & 0 & 0.009 & 0.5 & 0.22 & 0 \\
\hline 2 & & 346 & 20.2 & 1.81 & 0.02 & 0.018 & 0.124 & 0.7 & 0.17 & 0 \\
\hline 3 & & 566 & 26 & 0.03 & 0.03 & 0.005 & 0 & 0.1 & 0.26 & 0.01 \\
\hline 4 & & 326 & 20.3 & 0.06 & 0.05 & 0.007 & 0.008 & 0.2 & 0.54 & 0.01 \\
\hline 5 & 6.5 & 504 & 21.4 & 0.03 & 0.09 & 0 & 0.003 & 0.9 & 0.51 & 0 \\
\hline 6 & 6.8 & 1006 & 25.4 & 5.34 & 0.18 & 0.016 & 0.061 & 0.1 & 0.35 & 0 \\
\hline 7 & 7.8 & 336 & 20.6 & 2.85 & 0.09 & 0.004 & 0.003 & 0.3 & 0.83 & 0 \\
\hline 8 & & 488 & 26 & 1.54 & 0.12 & 0.005 & 0.007 & 0.8 & 0.34 & 0 \\
\hline 9 & 6.8 & 1122 & 22.5 & 0.88 & 0.05 & 0.008 & 0.029 & 0.3 & 0.26 & 0.06 \\
\hline 10 & & 201 & 25.6 & 0.05 & 0.04 & 0 & 0 & 0.1 & 0.19 & 0.01 \\
\hline 11 & & 466 & 25 & 0.28 & 0.24 & 0.009 & 0.009 & 0.9 & 0.1 & 0 \\
\hline 12 & 7.1 & 757 & 20.2 & 0.58 & 0.07 & 0.01 & 0.017 & 0.3 & 0.31 & 0.01 \\
\hline 13 & & 618 & 25.9 & 0.06 & 0.04 & 0.004 & 0.005 & 0.2 & 1.05 & 0.03 \\
\hline 14 & & 888 & 24.5 & 0.04 & 0.03 & 0.006 & 0.052 & 0.1 & 0.22 & 0.01 \\
\hline 15 & & 456 & 24.7 & 0.09 & 0.04 & 0.007 & 0.053 & 0.2 & 0.16 & 0.04 \\
\hline 16 & & 213 & 26.1 & 0.01 & 0.03 & 0.004 & 0.003 & 0.3 & 0.14 & 0 \\
\hline 17 & & 242 & 26.1 & 0.04 & 0.02 & 0 & 0.002 & 0.3 & 0.41 & 0 \\
\hline 18 & 7.1 & 968 & 23.8 & 0.23 & 0.15 & 0 & 0.01 & 0.3 & 0.24 & 0.01 \\
\hline 19 & 7 & 867 & 25.4 & 5.74 & 0.12 & 0.019 & 0.084 & 0.5 & 0.28 & 0 \\
\hline 20 & 6.5 & 590 & 19.6 & 10.5 & 0.51 & 0.019 & 0.019 & 1.3 & 0.12 & 0.013 \\
\hline 21 & 6.6 & 2160 & 28.1 & 2.15 & 2.16 & 0.01 & 0.014 & 0.8 & 0.28 & 0.03 \\
\hline 22 & 6.7 & 618 & 27.2 & 0.12 & 0.05 & 0 & 0.007 & 0.3 & 0.31 & 0 \\
\hline 23 & 7.3 & 1009 & 25.8 & 1.42 & 0.07 & 0.007 & 0.039 & 0.1 & 0.27 & 0.02 \\
\hline 24 & 7.2 & 918 & 23 & 0.15 & 0.17 & 0 & 0.013 & 0.8 & 0.27 & 0 \\
\hline 25 & 6.8 & 815 & 27.6 & 4.12 & 0.16 & 0.021 & 0.075 & 0.4 & 0.37 & 0 \\
\hline 26 & 7 & 255 & 21 & 5.5 & 0.23 & 0.011 & 0.05 & 0.1 & 0.1 & 0 \\
\hline 27 & & 332 & 27 & 0.64 & 0.22 & 0.024 & 0.238 & 0.3 & 0.16 & 0.07 \\
\hline & & & & & & & & & \\
\hline
\end{tabular}

"See Table 1

only elements showing clustering of similar values with depth were Fe and Co at depth scales equal to or exceeding $100 \mathrm{~m}$. Similar $\mathrm{Zn}$ concentrations were dispersed at depth scales of about $10 \mathrm{~m}$. Any correspondence between groundwater chemistry and depth must be viewed with caution as most of the wells were either fully screened or the screen interval was not known to the owner or manager of the well. The only exception was As Rank No. 26 (Tables 1 and 2) that was screened only over $1.5 \mathrm{~m}$.

A visual examination of As groundwater concentrations in the Kathmandu Valley did not suggest any clustering of similar As concentrations, meaning that there did not appear to be areas of the Kathmandu Valley where wells are more or less likely to be contaminated with As (Fig. 2). The visual conclusion was again tested statistically by performing Moran's Global I-test (Mitchell 2005) on the logarithms of concentrations, which did not show either clustering or dispersion of As concentrations with horizontal position over any horizontal distance scale (Fig. 6). Similar concentrations of $\mathrm{Ni}$ were clustered over distance scales 10 $-100 \mathrm{~m}$ and in the range $2500-4000 \mathrm{~m}$, while similar concentrations of $\mathrm{Cr}$ were clustered over a distance scale of $250 \mathrm{~m}$. The random distribution of As with regard to both depth and horizontal location is conistent with a fluvial recharge model in which As enters groundwater through randomly shifting losing streams and there is no net movement of As between groundwater and sediment within the sedimentary basin.

\section{DISCUSSION}

Since 2002 there have been six other small studies of groundwater As in the Kathmandu Valley (Khatiwada et al. 2002; Gurung et al. 2006; Bajracharya et al. 2007; Warner et al. 2008; Maharjan et al. 2009; Chapagain et al. 2009). Each study has examined a different set of wells and has presented a different set of As concentrations (Table 3). The maximum As concentration in our study was As $=2.07 \mathrm{mg} / \mathrm{L}$, which is the highest As concentration ever measured in the Kathmandu Valley. The maximum As concentration measured by Maharjan et al. (2009) was As $=0.265 \mathrm{mg} / \mathrm{L}$. By contrast, Gurung et al. (2006) and Warner et al. (2008) found maximum As concentrations of only As $=0.019 \mathrm{mg} / \mathrm{L}$ and $\mathrm{As}=0.021$ $\mathrm{mg} / \mathrm{L}$, respectively. The major difference between our results and those of others is that only we found As concentrations exceeding the Nepal Interim As Standard in dug wells. Maharjan et al. (2009) found As concentrations exceeding the WHO standard in $12 \%$ of dug wells. No other studies found As exceeding even the WHO standard in dug wells. We have no explanation for the discrepancies among studies except for chance and the small size of data sets as compared 
Table 3: Comparision of studies on groundwater arsenic in the Kathmandu Valley

\begin{tabular}{|l|c|c|c|c|c|}
\hline \multirow{2}{*}{ Study } & \multirow{2}{*}{ As (mg/L) } & \multicolumn{4}{|c|}{ Percentage (Number) } \\
\cline { 3 - 6 } & & Total TW & STW $^{2}$ & DTW & DW/Ss \\
\hline Khatiwada et al. (2002) & $=0.01$ & $18(82 \%)$ & 0 & $18(82 \%)$ & $9(100 \%)$ \\
\hline Max As = 0.0738 mg/L & $>0.01$ & $4(18 \%)$ & 0 & $4(18 \%)$ & $0(0 \%)$ \\
\hline Gurung et al. (2006) & $=0.01$ & $97 \%(28)$ & $100 \%(7)$ & $95 \%(21)$ & $100 \%(17)$ \\
\hline Max As = 0.019 mg/L & $0.011-0.05$ & $3 \%(1)$ & $0 \%(0)$ & $5 \%(1)$ & $0 \%(0)$ \\
\hline & $>0.05$ & 0 & $0 \%(0)$ & 0 & $0 \%(0)$ \\
\hline Bajracharya et al. (2007) & $=0.01$ & $87 \%(33)$ & & & $100 \%(38)$ \\
\hline Max As = 0.100 mg/L & $0.011-0.05$ & $8 \%(3)^{5}$ & & & $0 \%(0)$ \\
\hline & $>0.05$ & $5 \%(2)^{5}$ & & & $0 \%(0)$ \\
\hline Warner et al. (2008) & $=0.01$ & $90 \%(26)$ & $100 \%(23)$ & $50 \%(3)$ & $100 \%(29)$ \\
\hline Max As = 0.021 mg/L & $0.011-0.05$ & $10 \%(3)$ & $0 \%(0)$ & $50 \%(3)$ & $0 \%(0)$ \\
\hline & $>0.05$ & $0 \%(0)$ & $0 \%(0)$ & $0 \%(0)$ & $0 \%(0)$ \\
\hline Maharjan et al. (2009) & $=0.01$ & $60 \%(170)$ & $89 \%(132)$ & $28 \%(38)$ & $88 \%(77)$ \\
\hline Max As = 0.265 mg/L & $0.011-0.05$ & $34 \%(97)$ & $11 \%(17)$ & $60 \%(80)$ & $12 \%(10)$ \\
\hline & $>0.05$ & $6 \%(16)$ & $0 \%(0)$ & $12 \%(16)$ & $0 \%(0)$ \\
\hline Chapagain et al. (2009) & $=0.01$ & & & $48 \%(20)$ & \\
\hline Max As = 0.073 mg/L & $0.011-0.05$ & & & $40 \%(17)$ & \\
\hline this study & $>0.05$ & & & $12 \%(5)$ & \\
\hline Max As = 2.070 mg/L & $0.011-0.05$ & $0 \%(0)$ & $0 \%(0)$ & $0 \%(0)$ & $54 \%(7)$ \\
\hline & $>0.05$ & $36 \%(5)$ & $50 \%(3)$ & $25 \%(2)$ & $31 \%(4)$ \\
\hline
\end{tabular}

${ }^{1} T W=$ tubewell, ${ }^{2} S T W=$ shallow tubewell $($ depth $\leq 50 \mathrm{~m}),{ }^{3} \mathrm{DTW}=$ deep tubewell,$($ depth $>50 \mathrm{~m})$ ${ }^{4} \mathrm{DW} / \mathrm{SS}=$ dug $\mathrm{well} /$ stone spout, ${ }^{5}$ Personal communication from author, not in published study, and ${ }^{6}$ Pre-monsoon measurements only (some deep tubewells re-sampled during monsoon)

with the perhaps 30,000 tubewells and dug wells in the Kathmandu Valley (estimate based on relative populations of the Terai and the Kathmandu Valley and estimate of number of tubewells in the Terai by Pokhrel et al. 2009).

Gurung et al. (2007) argued that the geological setting of the Kathmandu Valley is consistent with the reductivedissolution model. Chapagain et al. (2009) presented evidence in favor of the reductive-dissolution model by showing statistically significant positive correlations between As and dissolved organic carbon (DOC), bicarbonate and ammonium, and a statistically significant negative correlation between As and oxidation-reduction potential (ORP). Chapagain et al. (2009) found As to be uncorrelated with either Fe or $\mathrm{Mn}$, as in this study. They also found As and sulfate to be uncorrelated, which is inconsistent with the sulfide-oxidation model. Chapagain et al. (2009) presented visual evidence that higher groundwater As concentrations occurred in the Central Groundwater District of the Kathmandu Valley, but did not verify their results statistically.

It is absolutely crucial that a common database be created of all measurements of groundwater chemistry in the Kathmandu Valley. This database must be continually rechecked every time new data are added for consistency with the existing models for As contamination and for clustering of similar values with either depth or horizontal location. We have made our contribution to this database

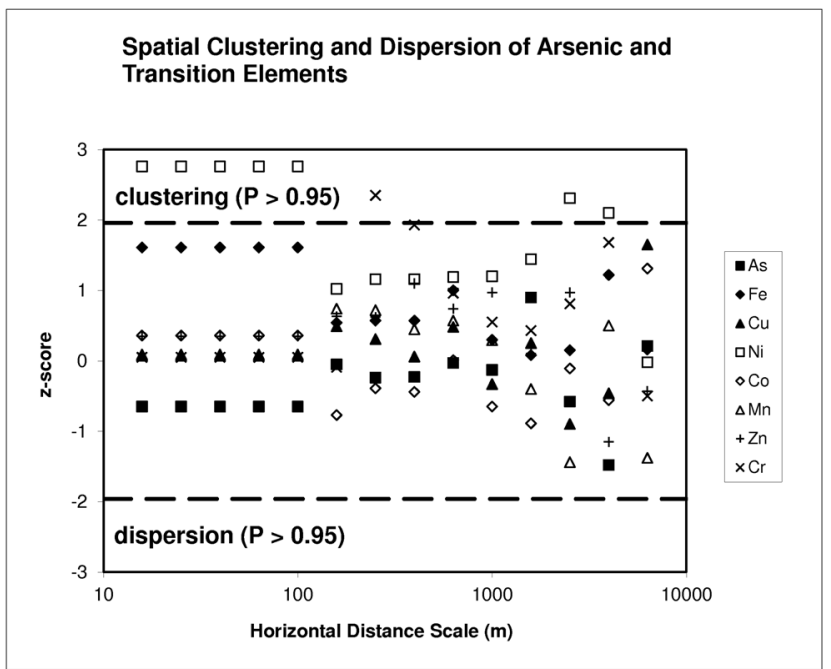

Fig. 6: Similar concentrations of $\mathrm{Ni}$ are clustered at horizontal distance scales $2500-4000 \mathrm{~m}$ and $10-100 \mathrm{~m}$, while similar concentrations of $\mathrm{Cr}$ are clustered at a horizontal distance scale of $250 \mathrm{~m}$. No other elements, including As, show clustering at any horizontal distance scale. The z-score is calculated using the Global Moran's ITest and the logarithms of concentrations $(\mathrm{mg} / \mathrm{L})$ in which values below the detection limit are set equal to the detection threshold (Mitchell 2005)

by including all our relevant data, including precise locations, in this paper. Recently, Bhatt and Gardner (2009) have published additional fluvial As measurements for rivers in the Kathmandu Valley, which are somewhat lower than the concentrations found by Emerman (2005). The As concentrations found by Bhatt and Gardner (2009) also tend to increase in the downstream direction, which suggests that some fluvial As in the Kathmandu Valley may result from pollution. Again, it is crucial that a common database be created of all surface water chemistry from the Kathmandu Valley.

\section{CONCLUSION}

The major new contribution of this study is that we have compared surface water As with groundwater As, unlike the other recent studies of As in the Kathmandu Valley. This comparison has shown consistency with the fluvial recharge model, in which elevated groundwater As results from losing streams with elevated As. The important implication of this model is that it implies that human activity could have an effect on the occurrence of groundwater As. Elevated surface water As throughout Nepal probably results from rapid erosion (Emerman 2005; Emerman et al. 2007), which is due to the monsoon climate and rapid tectonic uplift, but which is also accelerated by the deforestation occurring throughout Nepal, including the Kathmandu Valley. It is possible that the recharge of groundwater As could be affected by reversing the current rate of deforestation. At this point, it is 
crucial to keep testing the fluvial recharge model by comparing groundwater and surface water As in other tectonic valleys in the upper reaches of the Ganges River system, such as the Pokhara Valley.

\section{ACKNOWLEDGEMENTS}

This research was funded by William Robert Johnson, the Center for Engaged Learning (Utah Valley University) and the Department of Earth Science (Utah Valley University). Modifications and corrections suggested by two anonymous reviewers are gratefully acknowledged.

\section{REFERENCES}

Acharyya, S. K., Chakraborty, P., Lahiri, S., Raymahashay, B. C., Guha, S., and Bhowmik, A., 1999, Arsenic poisoning in the Ganges delta. Nature, v. 401, p. 545.

Acharyya, S. K., Lahiri, S., Raymahashay, B. C., and Bhowmik, A., 2000, Arsenic toxicity of groundwater in parts of the Bengal basin in India and Bangladesh: The role of Quaternary stratigraphy and Holocene sea-level fluctuation. Environ. Geol., v. 39, pp. 1127-1137.

Ahmad, S. A., Maharjan, M., Watanabe, C., and Ohtsuka, R., 2004, Arsenicosis in two villages in Terai lowland Nepal. Environ. Sci., v. 11, pp. 179-188.

Appelo, M., Van der Weiden, M. J. J., Tournassat, C., and Charlet, L., 2002, Surface complexation of ferrous iron and carbonate on ferrihydrite and the mobilization of arsenic. Environ. Sci. Technol., v. 36, pp. 3096-3103.

Aswathanarayana, U., 1997, Arsenic in groundwater, West Bengal. Jour. Geol. Soc. India, v. 49, pp. 341-345.

Badal, K. M., Roy Choudhury, T., Samanta, G., Basu, G. K., Chowdury, P. P., Chanda, C. R., Lodh, D., Karan, N. K., Dhar, R. K., Tamili, D. K., Das, D., Saha, K. C., and Chakraborti, D., 1996, Arsenic in groundwater in seven districts of West Bengal, India-The biggest As calamity in the world. Current Sci., v. 70, pp. 976-985.

Bajracharya, A. M., Yami, K. D., Prasai, T., Basnyat, S. R., Lekhak, B., 2007, Assessment of drinking water quality of Kathmandu metropolitan areas. Nepal Jour. Sci. Technol., v. 8, pp. 113118.

Bhatt, M. P. and McDowell, W. H., 2007, Evolution of chemistry along the Bagmati drainage network in the Kathmandu Valley. Water Air Soil Pollut., v. 185, pp. 165-176.

Bhatt, M. P. and Gardner, K. H., 2009, Variation in DOC and trace metal concentration along the heavily urbanized basin in the Kathmandu Valley, Nepal. Environ. Geol., v. 59, pp. 867-876.

Bhattacharaya, P., Chatterjee, D., and Jacks, G., 1997, Occurrence of As-contaminated groundwater in alluvial aquifers from the Delta Plains, Eastern India: Options for safe drinking water supply. Water Resour. Dev., v. 13, pp. 79-92.

Bhattacharya, P., Tandukar, N., Neku, A., Valero, A. A., Mukherjee, A. B., and Jacks, G., 2003, Geogenic arsenic in groundwaters from Terai Alluvial Plain of Nepal. Jour. Phys. IV France, v. 107, pp. 173-176.

Bloom, A. L., 1998, Geomorphology: A Systematic Analysis of Late Cenozoic Landforms, $3^{\text {rd }}$ ed., Prentice-Hall, Upper Saddle River, New Jersey, 482 p.

Bose, P. and Sharma, A., 2002, Role of iron in controlling speciation and mobilization of arsenic in subsurface environment. Water Res., v. 36, pp. 4916-4926.
Boyle, R. W. and Jonasson, I. R., 1973, The geochemistry of arsenic and its use as an indicator element in geochemical prospecting. Jour. Geochem. Explor., v. 2, pp. 251-296.

Brikowski, T. H., Smith, L. S., Shei, T.-C., and Shrestha, S. D., 2004, Correlation of electrical resistivity and arsenic contamination, Nawalparasi, Nepal. Jour. Nepal Geol. Soc., v. 30, pp. 99-106.

Brikowski, T. H., Smith, L. S. S., and Shrestha, S. D., 2005, Electrical resistivity profiling to delineate low groundwater arsenic target zones in the Terai, Nawalparasi, Nepal. Abstracts with Programs, Geol. Soc. Amer., v. 37, pp. 375.

Brikowski, T. H., Leybourne, M. I., Shrestha, S. D., Bhattacharya, P., Neku, A., and Smith, L., 2006, Geochemical indicators of groundwater arsenic mobilization mechanisms in the Ganges floodplain of Nepal. Abstracts with Programs, Geol. Soc. Amer., South-Central Sec., v. 38, pp. 8.

Cárceres, L., Gruttner, E., and Contreras, R., 1992, Water recycling in arid regions-Chilean case. Ambio, v. 21, pp. 138-144.

Chapagain, S. K., Shrestha, S., Nakamura, T., Pandey, V. P., and Kazama, F., 2009, Arsenic occurrence in groundwater of Kathmandu Valley, Nepal. Desalination Water Treatment, v. 4, pp. 248-254.

Chapagain, S. K., Pandey, V. P., Shrestha, S., Nakamura, T., and Kazama, F., Assessment of deep groundwater quality in Kathmandu Valley using multivariate statistical techniques. Water Air Soil Pollut., in press.

Chettri, M. and Smith, G. D., 1995, Nitrate pollution in groundwater in selected districts of Nepal. Hydrogeol. Jour., v. 3, pp. 71-76.

Collins, R. and Jenkins, A., 1996, The impact of agricultural land use on stream chemistry in the Middle Hills of the Himalayas, Nepal. Jour. Hydrol., v. 185, pp. 71-86.

Cresswell, R. G., Bauld, J., Jacobson, G., Khadka, M. S., Jha, M.G., Shrestha, M. P., and Regmi, S., 2001, A first estimate of groundwater ages for the deep aquifer of the Kathmandu Basin, Nepal, using the radioisotope chlorine-36. Ground Water, v. 39 , pp. 449-457.

Dahal, B. M., Fuerhacker, M., Mentler, A., Karki, K. B., Shrestha, R. R., and Blum, W. E. H., 2008, Arsenic contamination of soils and agricultural plants through irrigation water in Nepal. Environ. Pollut., v. 155, pp. 157-163.

Dhar, R. K., Biswas, B. K., Samanta, G., Mandal, B. K., Chakraborti, D., Roy, S., Jafar, A., Islam, A., Ara, G., Kabir, S., Khan, A. W., Ahmed, S. K., and Hadi, S. A., 1997, Groundwater As calamity in Bangladesh. Current Sci., v. 73, pp. 48-59.

Dongol, B. S., Merz, J., Schaffner, M., Nakarmi, G., Shah, P. B., Shrestha, S. K., Dangol, P. M., and Dhakal, M. P., 2005, Shallow groundwater in a middle mountain catchment of Nepal: Quantity and quality issues, v. 49, pp. 219-229.

Emerman, S. H., 2004, Deforestation, arsenic, and the selforganizing jungle in the Terai region of Nepal. Jour. Nepal Geol. Soc., v. 29, pp. 13-22.

Emerman, S. H., 2005, Arsenic and other heavy metals in the rivers of central Nepal. Jour. Nepal Geol. Soc., v. 31, pp. 11-18.

Emerman, S. H., Bhattarai, T. N., Adhikari, D. P., Joshi, S. R., Lakhe, S. L., Luhrs, A. J., Prasai, K. R., and Robson, K. L., 2007 , Origin of arsenic and other heavy metals in the rivers of Nepal. Jour. Nepal Geol. Soc., v. 35, pp. 29-36.

Emerman, S. H., Luhrs, A. J., Sandford, S. E., and Finken, A., Arsenic contamination of groundwater in Nepal as an issue of environmental justice, In: Bjørnerud, M., Emerman, S.H., Levy, S. A., and Schneiderman, J. S., (Eds.) The New Rocket Science: Putting Science to Work for Environmental Justice, chapter submitted to book in preparation. 
Environment and Public Health Organization (ENPHO) and United States Geological Survey (USGS), 2004, The state of arsenic 2003 in Nepal (a draft report). National Arsenic Steering Committee (NASC), Kathmandu, Nepal, 102 p.

Gurung, J. K., Ishiga, H., and Khadka, M. S., 2005, Geological and geochemical examination of arsenic contamination in groundwater in the Holocene Terai Basin, Nepal. Environ. Geol., v. 49, pp. 98-113.

Gurung, J. K., Ishiga, H., Khadka, M. S., and Shrestha, N. R., 2006, Comparison of arsenic and nitrate contaminations in shallow and deep aquifers of Kathmandu valley. Jour. Nepal Geol. Soc., v. 33, pp. 55-62.

Gurung, J. K., Ishiga, H., Khadka, M. S., and Shrestha, N. R., 2007, The geochemical study of fluvio-lacustrine aquifers in the Kathmandu Basin (Nepal) and the implications for the mobilization of arsenic. Environ. Geol., v. 52, pp. 503-517.

Harvey, C. F., Swartz, C. H., Badruzzaman, A. B. M., KeonBlute, N., Yu, W., Ali, M. A., Jay, J., Beckie, R., Niedan, V., Brabander, D., Oates, P. M., Ashfaque, K. N., Islam, S., Hemond, H. and Ahmed, M. F., 2002, Arsenic mobility and groundwater extraction in Bangladesh. Science, v. 298, pp. 1602-1606.

Hearn, P., Hare, T., Schruben, P., Sherrill, D., LaMar, C., and Tsushima, P., 2001, Global GIS Database: Digital Atlas of South Asia, U.S. Geological Survey Digital Data Series DDS62-C.

Kanel, S. R., Choi, H., Kim, K. W., and Moon, S.H., 2005, Arsenic contamination in groundwater in Nepal: A new perspective and more health threat in South Asia, In: Bundschuh, J., Bhattacharya, P., and Chandrasekharam, D., (Eds.) Natural Arsenic in Groundwater: Occurrence, Remediation and Management, A. A. Balkema Publishers, Leiden, pp. 103-108.

Karn, S. K. and Harada, H., 2001, Surface water pollution in three urban territories of Nepal, India, and Bangladesh. Environ. Manag., v. 28, pp. 483-496.

Khatiwada, N. R., Takizawa, S., Tran, T. V. N., and Inoue, M., 2002, Groundwater contamination assessment for sustainable water supply in Kathmandu Valley, Nepal. Water Sci. Technol., v. 46 , pp. $147-154$.

Lerda, D. E. and Prosperi, C. H., 1996, Water mutagenicity and toxicology in Rio Tercero, Cordoba, Argentina. Water Res., v. 30, pp. 819-824.

Langmuir, D., 1997, Aqueous Environmental Chemistry, PrenticeHall, Upper Saddle River, New Jersey, 600 p.

Maharjan, M., Shrestha, B. R., Shrestha, K. B., Shrestha, R. R., Raut (Khadka), R., Kafle, B., Ishihara, H., 2009, Arsenic contamination in groundwater resources in Kathmandu Valley, In: Takizawa, S., Kurisu, F., Satoh, H., (Eds.) Southeast Asian Water Environment, v. 3, IWA Publishing, pp. 73-79.

Maharjan, M., Watanabe, C., Akhtar Ahmad, Sk., and Ohtsuka, R., 2007, Mutual interaction between nutritional status and chronic arsenic toxicity due to groundwater contamination in an area of Terai, lowland Nepal. Jour. Epidemiol. Community Health, v. 61, pp. 389-394.

Maharjan, M., Shrestha, R. R., Akhtar Ahmad, Sk., and Watanabe, C., and Ohtsuka, R., 2006, Prevalence of arsenicosis in Terai, Nepal. Jour. Health, Popul. Nutr., v. 24, pp. 246-252.

Maharjan, M., Watanabe, C., Akhtar Ahmad, Sk., Ohtsuka, R., 2005, Arsenic contamination in drinking water and skin manifestations in lowland Nepal: The first community-based survey. Am. J. Trop. Med. Hyg., v. 73, pp. 477-479.

Mallick, S. and Rajgopal, N. R., 1996, Groundwater development in the arsenic-affected alluvial belt of West Bengal - some questions. Current Sci., v. 70, pp, 956-958.
McArthur, J. M., Ravenscroft, P., Safiullah, S. and Thirlwall, M. F., 2001, Arsenic in groundwater: Testing pollution mechanisms for sedimentary aquifers in Bangladesh. Water Resour. Res., v. 37, pp. 109-117.

McLaren, S. J. and Kim, N. D., 1995, Evidence for a seasonal fluctuation of arsenic in New Zealand's longest river and the effect of treatment on concentrations in drinking water. Environ. Pollut., v. 90, pp. 67-73.

Mitchell, A., 2005, The ESRI Guide to GIS Analysis, Volume 2: Spatial Measurements and Statistics, ESRI Press, Redland, California, $238 \mathrm{p}$.

Neku, A. and Tandukar, N., 2002, A report on arsenic programme (Mitigation measures and a training manual). Department of Water Supply and Sewerage, Ministry of Physical Planning and Works, Kathmandu, Nepal, 53 p.

Neku, A. and Tandukar, N., 2003, An overview of arsenic contamination in groundwater of Nepal and its removal at household level. Jour. Phys. IV France, v. 107, pp. 941-944.

Neku, A., Brikowski, T. H., Suenaga, K., Yokoto, H., Kshattry, I., and Ammann, L., 2006, Hydrogeology of a groundwater arsenic hotspot, Thulokunuwar Village, Nawalparasi, Nepal. Abstracts with Programs - Geol. Soc. Amer., South-Central Sec., v. 38, p. 7.

Neku, A. and Brikowski, T., 2009, Temporal variability of groundwater hydrochemistry in aquifers of Nawalparasi, Nepal. Abstracts with Programs - Geol. Soc. Amer., v. 41, pp. 32-33.

Nickson, R. T., McArthur, J. M., Burgess, W. G., Ahmed, K. M., Ravenscroft, P. and Rahman, M., 1998, Arsenic poisoning of Bangladesh groundwater. Nature, v. 395, pp. 338.

Nickson, R. T., McArthur, J. M., Ravenscroft, P., Burgess, W. G., and Ahmed, K. M., 2000, Mechanism of arsenic release to groundwater, Bangladesh and West Bengal. Appl. Geochem., v. 15 , pp. $403-413$.

Nimick, D. A., Moore, J. N., Dalby, C. E., and Savka, M. W., 1998, The fate of geothermal arsenic in the Madison and Missouri Rivers, Montana and Wyoming. Water Resour. Res., v. 34, pp. 3051-3067.

Panthi, S. R., Sharma, S., and Mishra, A. K., 2006, Recent status of arsenic contamination in groundwater of Nepal - A review. Kathmandu Univ. Jour. Sci. Technol., v. 2, pp. 1-11.

Pokhrel, D., Bhandari, B. S., and Viraraghavan, 2009, Arsenic contamination of groundwater in the Terai region of Nepal: An overview of health concerns and treatment options. Environ. Int., v. 35, pp. 157-161.

Polizzotto, M. L., Harvey, C. F., Li, G., Badruzzman, B., Ali, A., Newville, M., Sutton, S., and Fendorf, S., 2006, Soil-phases and desorption processes of arsenic within Bangladesh sediments. Chem. Geol., v. 228, pp. 97-111.

Robinson, B., Outred, H., Brooks, R., and Kirkman, J., 1995, The distribution and fate of arsenic in the Waikato River System, North Island, New Zealand. Chem. Spec. Bioavail., v. 7, pp. 89-96.

Saunders, L., 1998, A Manual of Field Hydrogeology, PrenticeHall, Upper Saddle River, New Jersey, 381 p.

Shanker, R., Pal, T., Mukherjee, P. K., Shome, S, and Sengupta, S., 2001, Association of microbes with arsenic-bearing siderite concretions from shallow aquifer sediments of Bengal delta and its implication. Jour. Geol. Soc. India, v. 58, pp. 269-271.

Sharma, S., Bajracharya, R. M., Situala, B. K., and Merz, J., 2005, Water quality in the Central Himalaya. Current Sci., v. 89, pp. 774-786.

Shrestha, R. R., Shrestha, M. P., Upadhyay, N. P., Pradhan, R., Khadka, R., and Maskey, A., 2003, Groundwater arsenic contamination, its health impact and mitigation program in Nepal. Jour. Environ. Sci. Health, v. A 38, pp.185-200. 
Shrestha, S. D., Brikowski, T., Smith, L., and Shei, T.-C., 2004, Grain size constraints on arsenic concentration in shallow wells of Nawalparasi, Nepal. Jour. Nepal Geol. Soc., v. 30, pp. 93-98.

Singh, T. B., 2004, Status of water quality in Kathmandu valley. Jour. Nepal Geol. Soc., v. 30, pp. 75-82.

Smedley, P. L. and Kinniburgh, D. G., 2002, A review of the source, behavior and distribution of arsenic in surface waters. Appl. Geochem., v. 17, pp. 517-568.

Tandukar, N., Bhattacharya, P., Jacks, G., and Valero, A. A., 2005, Naturally occurring arsenic in groundwater of Terai region in Nepal and mitigation options, In: Bundschuh, J., Bhattacharya, P., and Chandrasekharam, D., (Eds.) Natural Arsenic in Groundwater: Occurrence, Remediation and Management, A. A. Balkema Publishers, Leiden, pp. 41-48.

Van Geen, A., Radloff, K., Aziz, Z., Cheng, Z., Huq, M. R., Ahmed, K. M., Weinman, B., Goodbred, S., Jung, H. B., Zheng, Y., Berg, M., Trang, P. T. K., Charlet, L., Metral, J., Tisserand, D., Guillot, S., Chakraborty, S., Gajurel, A. P., and Upreti, B. N., 2008, Comparison of arsenic concentrations in simultaneously-collected groundwater and aquifer particles from Bangladesh, India, Vietnam, and Nepal. Appl. Geochem., v. 23 , pp. $3244-3251$.

Warner, N. R., Levy, J., Harpp, K., and Farruggia, F., 2008, Drinking water quality in Nepal's Kathmandu Valley: A survey and assessment of selected controlling site characteristics. Hydrogeol. Jour., v. 16, pp. 321-334.

Williams, V. S., Breit, G. N., Whitney, J., and Yount, J. C., 2004, Investigations on the relation of arsenic-bearing sediments to arsenic contaminated groundwater beneath the plains of Nepal. Abstracts with Programs - Geol. Soc. Amer., v. 36, pp. 558-559.

Williams, V. S., Kansakar, D. R., and Ghimire, B., 2005, Nepalese groundwater arsenic contamination is related to Siwalik source rock. Abstracts with Programs - Geol. Soc. Amer., v. 37, pp. 170.

Winkel, L., Berg, M., Amini, M., Hug, S. J., and Johnson, C. A., 2008, Predicting groundwater arsenic contamination in Southeast Asia from surface parameters. Nature Geosci., v. 1, pp. 536-542.

Wilkie, J. A. and Hering, J. G., 1998, Rapid oxidation of geothermal arsenic(III) in streamwaters of the eastern Sierra Nevada. Environ. Sci. Technol., v. 32, pp. 657-662. 